\title{
PCP lung nodules
}

\author{
Emad Abu Sitta, ${ }_{1}^{1}$ Xiaojin Sha, ${ }^{2}$ Komal Masood, ${ }^{1}$ Claudiu Georgescu ${ }^{1}$
}

${ }^{1}$ Internal Medicine- Infectious Disease, University of Toledo Medical Center, Toledo, Ohio, USA

2Pathology Department, University of Toledo Medical Center, Toledo, Ohio, USA

Correspondence to Dr Emad Abu Sitta, emademad70@hotmail.com

Accepted 6 February 2019

\section{DESCRIPTION}

A 54-year-old Caucasian man presented to the emergency department complaining of worsening productive cough, weight loss and left-sided chest pain lasting 1 month. He did not have a fever. $\mathrm{He}$ had a medical history of HIV diagnosed 22 years ago and had not been receiving any antiretroviral therapy (ART) for the last 8 years.

On physical examination on admission, his vital signs were as follows: heart rate was 72 beats per minute, respiratory rate was 16 breaths per minute, oxygen saturation was $97 \%$ on room air, with no fever, and his weight was $44.5 \mathrm{~kg}$. Chest examination revealed bilateral rales, worse on the right side. The rest of the physical examination was unremarkable. Laboratory investigations were significant for a white cell count of $3.2 \times 10^{9} / \mathrm{L}$, HIV RNA of 196388 copies $/ \mathrm{mm}^{3}$ and a CD4 cell count of $49 \times 10^{6} / \mathrm{L}$. A chest CT scan without intravenous contrast showed a left upper lobe (LUL) thick, irregular, walled cavitary lesion measuring $5.7 \times 4.9 \times 6.9 \mathrm{~cm}$ with no air-fluid level (as shown in figure $1 \mathrm{~A})$.

The differential diagnosis included an infectious (bacterial, mycobacterial or fungal) versus a malignant aetiology. Empirical treatment for pneumonia was initiated with ceftriaxone $2 \mathrm{~g}$ intravenously daily and metronidazole $500 \mathrm{mg}$ orally every 8 hours. Bronchoscopy did not reveal any intrabronchial lesions or purulence. Transbronchial biopsy was obtained and pathological examination showed no malignant cells, acid-fast stain was negative, and methenamine silver stain was positive for Pneumocystis pneumonia (PCP) (as shown in figure 2). Bacterial, fungal and acidfast cultures remained negative.

The patient was treated with trimethoprim/ sulfamethoxazole (TMP/SMX) 2 double strength (DS) tablets three times daily, and ART was started 3 weeks later. The patient's symptoms
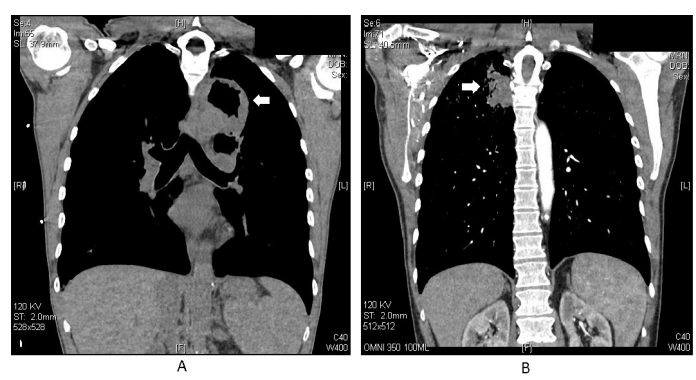

Figure 1 (A) Initial chest CT scan showing left upper lobe (LUL) thick wall cavitary lesion. (B) Repeated chest CT scan 3 months later showing a decrease in the size of LUL cavitary lesion but emerging right lung nodules.
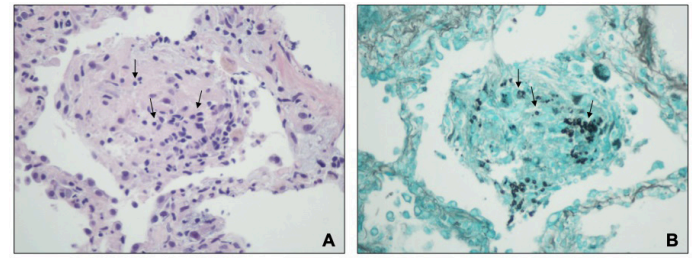

Figure 2 (A) Transbronchial biopsy shows chronic inflammation, acute activation with focal organisms (arrows). (B) Gomori Methenamine-Silver (GMS) stain of transbronchial biopsy shows Pneumocystis jirovecii organisms (arrows). Magnification $\times 800$.

improved; however, 3 months later, he experienced worsening cough and sputum production. Repeated investigation was significant for HIV RNA of 128 copies $/ \mathrm{mm}^{3}$ and CD4 count of $453 \times 10^{6} / \mathrm{L}$. A CT scan was obtained and showed a decrease in the size of the LUL cavitary lesion. In addition, a new right upper lobe mass-like lesion was found, measuring $2.4 \times 2.1 \mathrm{~cm}$, along with smaller multiple other right lung mass-like lesions (as shown in figure 1B). A CT-guided fineneedle aspiration of the largest right upper lobe lesion was performed. Pathological examination showed no malignant cells, and silver stain was again positive for Pneumocystis. Since these new lesions developed after a full course of treatment with appropriate doses of TMP/SMX, followed by prophylaxis, a decision was made to switch the treatment to atovaquone $750 \mathrm{mg}$ orally twice daily. One month later, the patient reported improved symptoms, less cough and an increase in weight.

Infection with Pneumocystis jirovecii is still a leading cause of opportunistic infections in patients with HIV with a low CD4 count, although the incidence has decreased significantly after initiation of ART. ${ }^{1}$ Patients usually present with gradual onset of shortness of breath and non-productive cough, along with fever. The most common radiological appearance is

Learning points

- Although a rare aetiology, Pneumocystis jirovecii infection should be considered in the differential diagnosis of cavitary lung lesions in patients with AIDS.

- Cavitary pneumonia due to Pneumocystis infection may respond slower and recur more frequently than the typical presentations with diffuse interstitial pneumonia. 
bilateral interstitial infiltrates; focal infiltrates, nodules and cavities are less common. ${ }^{2}$

Contributors EAS: primary author, wrote the manuscript and performed literature review. XS: reviewed the pathology slides, provided comments and performed literature review. KM: reviewed the manuscript and performed literature review. CG: reviewed and edited the manuscript, and performed literature review.

Funding The authors have not declared a specific grant for this research from any funding agency in the public, commercial or not-for-profit sectors.

Competing interests None declared.
Patient consent for publication Obtained.

Provenance and peer review Not commissioned; externally peer reviewed.

\section{REFERENCES}

1 Buchacz K, Baker RK, Palella FJ, et al. AIDS-defining opportunistic illnesses in US patients, 1994-2007: a cohort study. AIDS 2010;24:1549-59.

2 Kales CP, Murren JR, Torres RA, et al. Early predictors of in-hospital mortality for Pneumocystis carinii pneumonia in the acquired immunodeficiency syndrome. Arch Intern Med 1987:147:1413-7.

Copyright 2019 BMJ Publishing Group. All rights reserved. For permission to reuse any of this content visit

https://www.bmj.com/company/products-services/rights-and-licensing/permissions/

BMJ Case Report Fellows may re-use this article for personal use and teaching without any further permission.

Become a Fellow of BMJ Case Reports today and you can:

Submit as many cases as you like

- Enjoy fast sympathetic peer review and rapid publication of accepted articles

- Access all the published articles

Re-use any of the published material for personal use and teaching without further permission

For information on Institutional Fellowships contact consortiasales@bmjgroup.com

Visit casereports.bmj.com for more articles like this and to become a Fellow 